\title{
Policy advice for public participation in British Columbia forest management
}

\author{
by C. Tyler DesRoches ${ }^{1}$
}

\begin{abstract}
This paper explores the current status of public participation in BC forest management with the objective of finding ways to improve it at the policy level. Public participation is discussed in relation to features of deliberative democratic theory and then within the historical context of $\mathrm{BC}$ forest management. Recent public complaints concerning inadequate participatory opportunities received at the Forest Practices Board and the move to diminish the extent of public participation in land-use planning is discussed. This paper maintains that effective public participation should be a goal of public forest management and that a corresponding policy should be devised.
\end{abstract}

Key words: public participation, forest management, legitimacy, British Columbia

\section{RÉSUMÉ}

Cet article explore l'état actuel de la participation du public en matière d'aménagement forestier en C.-B. dans le but de trouver des moyens de l'améliorer lorsqu'il est question de politiques forestières. La participation du public est discutée en fonction des caractéristiques de la théorie du droit de parole en démocratie et par la suite en fonction du contexte historique de l'aménagement forestier en C.-B. Les récentes plaintes du public au sujet de l'absence d'opportunité de participation reçues par le Forest Practices Board et la tendance à diminuer l'étendue de la participation du public en matière de planification de l'utilisation du territoire sont discutées. Cet article indique que la participation effective du public devrait être un objectif de l'aménagement des forêts publiques et qu'une politique en la matière devrait être élaborée.

Mots clés : participation publique, aménagement forestier, légitimité, Colombie-Britannique

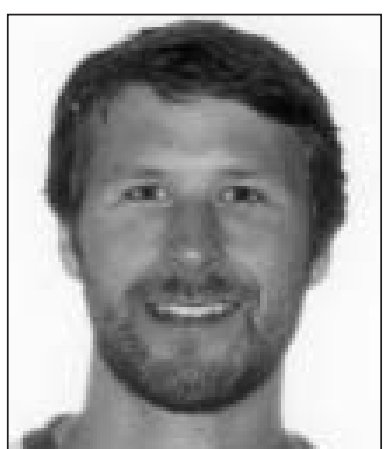

C. Tyler DesRoches

\section{Introduction}

The demand for public participation in decisions regarding forest management is now a critical issue in many jurisdictions following the global shift to sustainable forest management. Although the forests in British Columbia (BC) currently face a mountain pine beetle epidemic, job losses due to a prevalence of mill closures and increasing international competitiveness pressures, public participation is atop the list of public concerns in provincial forest management. In fact, inadequate opportunities to participate in forest management are a leading public complaint received by the official "watchdog" of forestry in BC, the Forest Practices Board (FPB Updated). Recent surveys also indicate the importance of public participation-British Columbians believe increasing public education and participation are the most effective ways to enhance the credibility of forest managers (Bredin 2003, BC Statistics 2005). Although the public's position may sound predictable to some, others may suspect the concern is mistaken, particularly given the prima facie participatory opportunities available to the average citizen.
The $\mathrm{BC}$ government has jurisdiction over all of the public land (approximately 95\% of the landbase), including forests, except for federal lands contained in National Parks, and Military and Native reserves. These publicly owned forests are managed in the public interest. ${ }^{2}$ The history of public participation in $\mathrm{BC}$ is a short one and is primarily concentrated over the last 15 to 25 years. Indeed, throughout the province's history, from its inception in 1846, to its amalgamation with Canada in 1871, and until the 1970s, forest land-use decisions did not involve any formal sort of public participation. ${ }^{3} \mathrm{~A}$ likely cause of this exclusion was that, for most of BC's history the use of forest land was largely in agreement and forest management itself was largely seen as an activity best undertaken by expert scientists and foresters. At this time, forests were primarily used for trees that were fashioned into traditional forest products like lumber, pulp and paper, and structural panels.

Beginning in the 1960s and '70s, the timber-centric mandate of forest management in BC began to evolve and with it,

\footnotetext{
${ }^{2}$ Section 4.1 of the British Columbia Foresters Act makes Registered Professional Foresters legally bound to "serve and protect the public interest." For a discussion of the concept "public interest," see ABCFP (2002). Serving the public interest is also central to the British Columbia Ministry of Forests' stated goals.

${ }^{3}$ Prior to this, opportunities for public involvement existed from time to time through briefs submitted to royal commissions, discussion papers, etc. (Niezen 1987).
}

\footnotetext{
${ }^{1}$ Forest Economist with the Industry, Trade \& Economics Research Program , Pacific Forestry Centre, Canadian Forest Service, Natural Resources Canada, 506 West Burnside Rd. Victoria, British Columbia V8Z 1M5. E-mail: tylerdesroches@yahoo.ca.
} 
amendments to legislation and policy soon followed. With the popularization of multiple-use forestry and a public demanding greater involvement in decision-making processes, public participation became official policy at the British Columbia Ministry of Forests (BC MoF) (CORE 1995a). Although this policy was officially adopted in 1983, a comprehensive public participation policy for forest management has never been developed. Nevertheless, extended consensus-based, strategic-level public participation did flourish, mostly during the 1990s. The provincial land-use planning initiatives such as those spearheaded by the Commission on Resources and Environment (CORE) and the Land and Resources Management Plans (LRMPs) processes were seen by many as the cornerstone of public participation, not only in forest management, but as an invaluable means for resolving disputes in land-use planning across the province.

Though it is clear that public participation in forestry is more common today than it was in the early 1970s, it is equally obvious that the number of opportunities is not all that matters-quality is a fundamental concern. Today, there are opportunities for public participation at the operational level, mainly through review and comment on proposed Forest Stewardship Plans and during Timber Supply Reviews. However, the FPB recently concluded that public participation as legislated under the new Forest and Range Practices Act (FRPA) is inadequate. Moreover, while the LRMP process continues in a few regions of the province, it will probably be concluded in the near future (BC MAL 2006). As will be discussed below, the decision to transform the strategic-level decision-making process from a stakeholder-led, consensusbased process to one that is government-led and restricted to key stakeholders is questionable, particularly given the public's continued insistence to participate in forest management (FPB 2002, BC Statistics 2005).

This paper aims to explore the current status of public participation in BC forest management and to provide policy-level recommendations. ${ }^{4}$ In particular, a key objective is to improve the understanding of why complaints about public participation are so common in light of the opportunities currently available to British Columbians. In addition to the introduction and conclusion, the paper is organized as follows. The first section presents an overview of the concept "public participation" and its relation to features of deliberative democratic theory. The second section outlines a history of public participation in $\mathrm{BC}$ forest management. The third section discusses the recent public complaints concerning public participation at the operational-level and other potential problems that may arise if public participation is diminished at the strategic-level of planning. In the fourth section, practical policy-level recommendations are made to improve the state of public participation in $\mathrm{BC}$ forest management.

\section{Public Participation in Forest Management}

Over the last few decades, the tendency towards incorporating some kind of public participation in forest policy and planning decisions has become widespread (CCFM 1992, CIF

\footnotetext{
${ }^{4}$ This paper does not concern detailed recommendations for specific participatory opportunities, nor does it consider opportunities mandated outside of governmental jurisdiction (e.g., certification schemes, civil disobedience).
}

1998, Duinker 1998, FAO 2004). A recent version of the Encyclopaedia of Forestry Science defines public participation in forest policy decision-making as:

"...various forms of direct public involvement where people individually or through organized groups, can exchange information, express opinions and articulate interests, and have the potential to influence decisions or the outcome of specific forestry issues" Sheppard and Achiam (2004).

This definition points to various degrees and types of public participation. The Joint FAO/ECE/ILO Committee on Forest Technology, Management and Training recently conducted a study on participation in forestry in Europe and North America. Across three levels-national, regional and local- the Committee describes four types of public involvement processes. These include: (1) those addressing forest policies, programs, and plans, (2) those promoting specific forest projects, (3) those used in audits of forestry projects or practices, and (4) those involving advisory boards or permanent councils (FAO 2004). Within the various types and levels of public participation, different techniques are said to exist along a "continuum" of public participation (Beckley et al. 2006). Such techniques can range from the simple provision of public information to deliberative bodies with fully delegated authority (Brenneis 1990). Other modern tools might include public advisory committees, focus groups, public multi-criteria analysis, citizen juries, and deliberative polling (Beckley et al. 2006). The level of participation and the tools selected for a particular task can vary for a myriad of reasons, including: the level of interest or disagreement shown by the public in an issue, the perceived credibility of the public participation exercise, the stage of planning in a management scheme, the available funding, and the degree of authority that a governing body delegates to the public. Benefits of effective public participation are said to increase awareness of forestry issues, enhance the mutual recognition of varied interests and knowledge of forests and their uses, improve the provision of multiple forest goods and services, enhance acceptance of forest policies, plans and operations, increase transparency and accountability of decision-making, and build trust in institutions (Montpetit 2003, FAO 2004, Sheppard and Achiam 2004).

Given the multi-faceted character of public participation, it is not surprising that evaluations can be fraught with methodological problems (Conley and Moote 2003). For example, what is "effective" public participation and according to whom? Indeed, the non-existence of objective criteria ${ }^{5}$ to evaluate the effectiveness of public participation is commonly perceived as an obstacle to improving it. Rowe and Frewer (2004) state, "Given the variety of forms of participation mechanisms, and their seemingly diverse aims, the question arises as to whether it is possible or sensible to talk about a definition of public participation effectiveness in any gen-

${ }^{5}$ The non-existence of objective criteria does not imply that those evaluative standards championed by, for example, Beckley et al. (2006) or Frame et al. (2004) are merely subjective. Arguably, such criteria are something "in between" the confines of subjectivity and objectivity. They are more consequential than mere subjectivity implies, and yet to suggest they are "objective" in a strict sense conveys an unrealistic inflexibility. 
eral sense." Nevertheless, researchers and others have developed influential lists of criteria to evaluate effective public participation; ultimately, such lists derive from two sourcestheoretical conjecture and/or through the collection of empirical evidence. In the context of $\mathrm{BC}$ forest management and provincial land-use planning, noteworthy evaluations of public participation have been completed by Brenneis (1990) and Frame et al. (2004), respectively. In her evaluation (a background paper to the BC Forest Resources Commission), Brenneis discusses "significant components" of a public participation process, which include: a legal mandate, comprehensive public participation opportunities, access to information, adequate resources for participation, written responses, conflict resolution mechanisms, appeal mechanisms, and advisory bodies. The 25 process and outcome evaluative criteria for collaborative planning ${ }^{6}$ developed by Frame et al. (2004) include items such as inclusive representation, voluntary participation and commitment, accountability, the reduction of conflict, service to the public interest and agreement met by all parties. Deliberative democracy, in particular, has the potential to improve our understanding of effective participatory opportunities at a theoretical level. Indeed, it has already significantly influenced the academic literature pertaining to public participation and, thus, a brief discussion is in order.

\section{Democratic theory}

Deliberative democratic theory has recently been linked to public participation, while Jürgen Habermas's discourse-theoretic approach in particular has influenced the work of numerous researchers (Webler 1995, Parkins 2002, Abelson et al. 2003, Montpetit 2003, Stedman and Parkins 2004). This approach offers an account of the public use of reason that explains the rationality of deliberation in terms of ideal reason-giving procedures (Bohman 2000). At the centre of Habermas's theory is the "Ideal Speech Situation" (ISS). Chambers (1996) explains, "To think that something could go wrong with communication is to assume that there is a form of communication in which nothing goes wrong; it is to presuppose an ideal form of communication that stands as a counterfactual background to our conversations." The ISS is a regulative ideal where arguments are won only by good reasons while things like freedom of access, equal rights to participate, truthfulness on the part of participants, and absence of coercion in taking positions are all elements making up the public discourse (Habermas 1993). Thus, the ISS embodies a "...form of communication ...free of the kinds of distortions that impede the argumentative search for truth or rightness" (Cronin 1993). ${ }^{7}$ The following "rules" are said to be constitutive of an ISS (White 1988):

I. Each subject who is capable of speech and action is allowed to participate in discourses.

\footnotetext{
$\overline{{ }^{6} \text { See Gunton and Day (2003) for an overview of the theory of col- }}$ laborative planning.

${ }^{7}$ This form of communication is often referred to as "communicative action" or understanding oriented action-which can be contrasted with strategic action or self-interested action common in economic theory.
}

II. a. Each is allowed to call into question any proposal.

b. Each is allowed to introduce any proposal into the discourse.

c. Each is allowed to express his attitudes, wishes, and needs.

III. No Speaker ought to be hindered by compulsionwhether arising from inside the discourse or outside of it—from making use of the rights secure under [I and II].

It is important to mention the potential for applying the ISS in a practical sense. Indeed, to suggest it can be attained in a real-life public discourse setting is highly dubious. Recognizing this difficulty, Habermas maintains that efforts should be put forward to arrive at an approximate ISS. The road to improving public participation thus can be seen as a continuous conversation that takes advice from the normative ideals embodied by the ISS. There is always room for improving participatory opportunities and whether pragmatic or not, the ISS provides the standard to evaluate reallife public discourses (Chambers 1996).

Deliberative democratic theory entails the direct engagement of citizens (or their representatives) in a public discourse setting where arguments are defended with the "public use of reason." Gutmann and Thompson (2004, emphasis added) state, "Most fundamentally, deliberative democracy affirms the need to justify decisions made by citizens and their representatives." Central to deliberative democracy is public debate-to test our reasons in a public setting with the prospect of improving public decisions. Bohman (2000) explains, "The positive ideal is the participation of all citizens in decision making, widely dispersing power in society. Even if deliberation takes place in representative bodies... [s] uch bodies remain deliberative only if citizens vote for and choose their representatives on the basis of participation in public debate and discussion of issues."

Legitimacy is also an important element of deliberative democratic theory and has also been shown to be a fundamental component of effective public participation in BC forest management (Mascarenas and Scarce 2004). Simply stated, democratic legitimacy is the outcome of "free and reasoned agreement between equals" (Cohen 1997). The term "equals" in this context does not imply that citizens have equal abilities or social status, but that their statements are given equal respect in a discourse setting. This notion of legitimacy can be more easily understood when contrasted with its description in the representative model of democracy. ${ }^{8}$ The latter is characterized by elected politicians who, on Election Day, are delegated the authority to make decisions on behalf of the electorate. "In a representative democracy the people do not rule, though they decide who shall rule. The rulers are officials selected in an electoral competition among contestants who are by no means ordinary men and women but instead belong to an elite of intelligence, cunning, connections, charisma, and other attributes that enable them to present themselves to the public plausibly as "the best" "(Posner 2003, quotes in the original). This entrustment recognizes public decisions, when made by elected officials and

${ }^{8}$ Posner (2003) labels deliberative democracy and representative democracy as Concept 1 and Concept 2 democracy, respectively. 
their bureaucracies, as embodying legitimacy. Simply stated, the public use of reason is not required for legitimacy in the representative model where it is broadly understood as stable public opinion - an interpretation of legitimacy that is independent of cognition. ${ }^{9}$

Because the representative and deliberative models envision democratic legitimacy in different ways, each can expect to promote different levels and types of public participation in collective decision-making. In the deliberative model, direct participation of the citizenry in the public sphere ${ }^{10}$ is a necessary requirement of legitimacy — whether it is to elect representatives or to be involved in public decision-making processes. On the other hand, the representative model may have a role for public participation, but it is not necessarily a deliberative one, nor is it required for legitimacy. Thus, if the prevailing theory of democracy leans towards the deliberative model, then public participation-formalized or not-is necessary to establish legitimacy.

Interestingly, the $\mathrm{BC}$ Forest Resources Commission (FRC) acknowledged the public's insistence for genuine opportunities to participate in 1991, likening the development to a society distancing itself from the representative model of democracy and moving towards a more participatory one (FRC 1991). Such a shift implies a change in the average citizen's notion of legitimacy and the ensuing processes necessary to attain it. The public's demand for involvement in public decisions is a call for the public use of reason primarily because it provides participants with a sense of legitimacy. To summarize, when a deliberative model of democracy is favoured, even when housed within a larger representational model, the public use of reason as a mechanism to justify decisions is a requirement to attain legitimate outcomes.

\section{A History of Public Participation in BC}

Prior to the late 1970s public participation in BC forest management was virtually non-existent. In 1979-1980, legislation and policy concerning public participation was preceded by a few important catalysts, namely, the Environment and Land Use Committee of Cabinet (ELUC), the Pearse Royal Commission, and the Forest Land Use Liaison Committee. In 1973 the government established the ELUC (involving various stakeholders), which was meant to provide better coordination between the land and resource ministries, and to confront emerging conflicts. Three years later, the Pearse Royal Commission recommended the government manage public forests in balance with other forest values, in addition to timber, such as recreation and protected areas. For the first time in BC's history, multiple-use forestry was becoming normalized in the province. In 1978, the Forest Land Use Liaison Committee, a body comprised of environmental groups and industry representatives, submitted a Consensus Statement on Public Involvement that stated, “.... all British Columbians have the right to a role in the development of forest land use decisions; to support public participation in forest land use in British Columbia; and to suggest ways in which the public role can improve."11 Together, these three instruments of

\footnotetext{
${ }^{9}$ I thank Kenneth L. Avio for this point.

10 "The public sphere is normative ideal-a realm of social life where private people come together as a public to engage in debate over the general rules that govern their lives" (Parkins 2002).

${ }^{11}$ Forest Land Use Liaison Committee (1978).
}

change led the way for the formalization of public participation in BC forest management, and by the late 1970s legislation and policy would be introduced.

In 1979, the provincial government introduced the new Forest Act, Ministry of Forests Act, and Range Act. ${ }^{12}$ Although these first two acts mentioned brief opportunities for the public to review and make comments on operational plans, it was not until a year later that the ministry's "Public Involvement Program" was launched. A key objective of this program was to, "... make public involvement an integral part of forest planning and recognize that planning and public involvement are not separate procedures..." (BC MoF 1984, Chap. 2). Shortly thereafter an interim Public Involvement Policy and Public Involvement Handbook were published. Officially adopted in 1983, the policy was, “...to provide an interim framework for the conduct of the BC MoF's Public Involvement Program" and included several policy statements that primarily focused on participation at the operational level—creating opportunities for public review and comment on forestry plans for relatively small tracts of land. ${ }^{13}$ By this time, several advisory groups in different regions were also well underway in the province.

During the early 1980s, the BC MoF was leading several region-specific decision-making processes exclusively for areas experiencing conflict. Public participation at the regional level took on various forms, such as regional management committees, task forces and advisory groups. The South Moresby Planning Team, the Tahsish Task Force, and the Meares Island Planning Team, were formed to deal mainly with disputes regarding the harvesting or preservation of forest land. Although such regional decision-making groups were, at that time, occurring in isolated geographic pockets across the province, province-wide land-use planning had not yet materialized.

After considering a variety of public responses to the Public Involvement Policy, in 1984 the BC MoF made revisions and included it in the official Planning Manual (Doliner 1982). The manual defines public involvement as, "...the involvement at the working level of various individuals, groups, corporations, or agencies in developing and implementing forest management plans and programs. It is a mechanism through which an interested party can influence management decisions on forest lands and the way in which the forest service can communicate regularly with citizens" (BC MoF 1984, Chap. 2). This version of the policy also explained some general public involvement methods (public

\footnotetext{
${ }^{12}$ Statutory authority regarding public participation in the new legislation include sections 27(c) and 34(3) of the Forest Act 1979, which state that the government cannot enter into a tree farm license agreement or pulpwood agreement without first holding a public hearing, and S. 4(c) of the Ministry of Forests Act 1979 which stipulates that the government, in planning forest resources, must co-operate and consult with the private sector. The "private sector" it need be mentioned, was understood to include the public (Brenneis 1990).

${ }^{13}$ Responsibility to initiate contacts outside the ministry, Responsibility for initiating and conducting specific public involvement activities, Public involvement in Timber Supply Area Plans, Public access to management and working plans for tree farm licenses, Advisory status of sponsored groups, Support services for sponsored groups, Annual report on public involvement (BC MoF 1981).
} 
information, consultation methods and extended involvement methods) to be employed by ministerial staff.

In the late 1980s there was a growing interest in BC for sustainable development, a concern spearheaded in 1987 by the "Brundtland report"(World Commission on Environment and Development 1987). As noted in CORE (1995a), "The Brundtland report articulated many of the concerns being raised in the land use debate in $\mathrm{BC}$ and contributed to the public demands that the government act more forcefully to develop cooperative arrangements involving the public in land use decisions affecting their communities." The goal of sustainable development meant that a province-wide landuse plan was necessary. Thus, in late 1988, 51 individuals, 34 agencies and public and private interest groups met at Dunsmuir Lodge (Sydney, BC) where they drafted an agreement-The Dunsmuir Agreement on Provincial Land Use Strategy - regarding the need for a provincial land and water use strategy. Also in June 1989, the government established the FRC and the BC Round Table on the Environment and the Economy shortly thereafter, in January 1990. The outcome of these bodies was overwhelmingly in harmony with the Dunsmuir Agreement: to move forward with developing a comprehensive and co-ordinated provincial land-use plan-one that would facilitate the sustainability objective.

Given full powers of inquiry to independently review BC forest management, the FRC reported in April 1991. The Commission was assigned four initial tasks, including an exploration into ways to improve public participation in forest planning and management. The Commission recommended that, "All major areas where public participation is required in the planning and management of forest land based activities be enshrined in legislation" (FRC 1991). Embodied within this argument was that statutory authority was necessary to enhance the credibility of public participation in decision-making. The Commission also argued that although the $\mathrm{BC} \mathrm{MoF}$ had put forward versions of a public involvement policy in 1981 and 1984, it still did not have a comprehensive document that would facilitate the public's desire to participate in meaningful forest planning and decision-making opportunities.

The BC MoF never directly confronted this law-making appeal for "in-depth" public participation that was recommended by both the FRC and, shortly thereafter, by the Commission on Resources and Economy (CORE). This decision was made primarily because of the considerable degree of ambiguity surrounding the broad notion of public participation. It had been declared at the Public Involvement Conference of 1980 that public participation required a variety of methods-processes that could not be easily legislated-without resulting in unnecessary inflexibility (Niezen 1987). Moreover, after attempting to devise a more comprehensive public participation policy in the late 1980s, the undertaking was in some ways abandoned. In 1993, a new Ministry Policy Manual replaced all prior policies, including Chapter 2 of the 1984 manual. Although there was a section reserved for a new ministerial public involvement policy in the outline of the 1993 Policy Manual, it was introduced as a work in progress and continues to be so in $2007 .{ }^{14}$ Although

\footnotetext{
${ }^{14}$ See Chapter 6 of the BC MoF Policy Manual, updated March, 2006: http://www.for.gov.bc.ca/tasb/manuals/policy/resmngmt/ rm-toc.htm
}

the call to adopt a more robust legislation was once again rejected in the early 1990s and the public involvement policy was neglected, consensus-based public participation in provincial land-use planning was gaining a foothold in the province.

The CORE was established in 1992 and was disbanded in 1996 (Wilson 1998). As an external Commission, the CORE was legislated to develop “.... B British Columbia-wide strategy for land use and related resource and environmental management" (CORE 1993). A significant responsibility of the CORE was to achieve consensus on land-use in areas that were established by four regional "tables"- Vancouver Island, CaribooChilcotin, East Kootenay, and West Kootenay-Boundary. These regional plans were meant to be prepared with the active participation of various interest groups. The plans were "...intended to designate land resources for a variety of purposes, ranging from intensive resource development to protected areas, in keeping with the government's commitment to double the amount of protected area from 6 to $12 \%$ of the province, while accommodating and sustaining a full range of land use values, and encouraging a strong and more diversified economy" (CORE 1995b). With respect to recommendations concerning public participation, the CORE suggested similar changes to those proposed by the FRC-public participation was promoted as one of the five key components of the sustainable land-use planning in the province. Moreover, recommendations included creating a comprehensive government-wide policy to describe and define criteria for public participation processes, to develop statutory recognition of the rights and responsibilities of public participation in the province, and that participants should follow a Code of Conduct ${ }^{15}$ when engaged in participatory processes.

After CORE submitted the regional land-use plans to Cabinet in 1994, the land use co-ordination office (LUCO) was established. LUCO was meant to complement the work done by CORE and was later placed in charge of managing the subregional land-use strategies-LRMPs-across the province. Much like the regional table process initiated by CORE, these sub-regionally focused processes aimed at achieving consensus among stakeholders, which initially included any BC citizen with an interest in public land use. ${ }^{16}$

LRMPs each cover an area of anywhere between 15000 and 25000 square kilometers in size, typically take between two to five years to complete, and have a lifespan of approximately 10 years. The process is managed by a planning table comprised of between 20 and 45 stakeholders representing all major interests, including: forestry and mining representatives, range representatives, community groups, tourism associations, environmental groups, First Nations and public recreationalists (Grzybowski and Associates 2001). Each LRMP process not only results in a unique plan but is subjected to different pressures according to the interests of stakeholders at a particular planning table. When early LRMPs were being developed, a main purpose of the process was to establish legally enforceable "Higher Level Plans"plans that deal specifically with forestry practices-within a

\footnotetext{
${ }^{15}$ See CORE (1995b).

${ }^{16}$ From the LRMP guidelines (British Columbia 1993): “...anyone directly affected by land use decisions, as well as any member of the public with an interest in land use or resource management, should be encouraged to participate."
} 
Table 1. Historical categories of public participation in BC forest management

\begin{tabular}{lll}
\hline Categories & Description & Examples \\
\hline Operational & $\begin{array}{l}\text { Site-specific opportunities that are largely confined } \\
\text { to "review and comment" types of participation. }\end{array}$ & Forest Stewardship Plans and Timber Supply Reviews. \\
Strategic & $\begin{array}{l}\text { Extensive participatory decision-making opportunities } \\
\text { that include a variety of stakeholders and interests. }\end{array}$ & $\begin{array}{l}\text { Collective opportunities made available through the } \\
\text { CORE, LRMPs and SRMPs. }\end{array}$ \\
Ad hoc & $\begin{array}{l}\text { Opportunities established for a specific purpose and } \\
\text { with a time horizon. These can be at the operational } \\
\text { or strategic-level. }\end{array}$ & $\begin{array}{l}\text { Dunsmuir, Old Growth Strategy, Protected Areas } \\
\text { Strategy. }\end{array}$ \\
\hline
\end{tabular}

sub-region. These strategic level plans set out the boundaries for the various values and interests attached to lands. Operational plans for specific forestry activities are secondary to the higher level plans, which, after being approved by the Provincial Cabinet, establish borders or restrictions for different activities in a particular zone in an LRMP. The CORE and LRMP processes marked an important point in the history of public participation in $\mathrm{BC}$ forest management. Although these programs were not initiated for forest management alone-they were for land-use planning more generallythey had obvious implications for provincial forestry, including the participatory opportunities. These strategic-level processes were the first attempt at achieving consensus-based solutions to land-use planning problems in BC.

There were other pieces of legislation introduced in the mid-1990s that affected public participation, if only in a modest way. In 1994, the Forest Renewal Act, the Forest Practices Code of British Columbia Act and the Forest Land Reserves Act were presented to the BC Legislative Assembly. Among these documents, the Forest Practices Code (the Code), included a "Public Consultation Guidebook," a type of instruction manual for engaging the public as required by the legislation. The Code also authorized the creation of the FPB. However, when the Code was but four years old in 1999, the $\mathrm{BC} \mathrm{MoF}$ announced the need for a forest policy review and this process, as anticipated, marked the beginning of the end of the Code and the gradual adoption of the Forest and Range Practices Act (FRPA). While similarities to the requirements for public participation under the Code remain intact today, the $\mathrm{BC} \mathrm{MoF}$ has a few added responsibilities and is now called "the Ministry of Forest and Range and Minister responsible for Housing" (BC MoFR).

Although public participation continues at the strategiclevel, there have been some changes recently. Land-use planning became the responsibility of the Ministry of Sustainable Resource Management in 2001 and is now assigned to the Integrated Land Management Bureau (ILMB) of the British Columbia Ministry of Agriculture and Lands (BC MAL). The LRMPs and regional plans devised under CORE are now called "Strategic Land Use Plans" (SLUP). Following completion of the SLUPs, another more detailed level of planning referred to as, "Sustainable Resource Management Plans" (SRMPs) was introduced. SRMPs are technical plans that take their directions from existing government-approved strategic policies and plans. They were primarily introduced to facilitate resource management decisions for small to mediumsized landscapes or watersheds within an LRMP. While approximately $85 \%$ of provincial crown land are now covered by SLUPs, the BC MAL is now moving towards a formal conclusion of the stakeholder-led strategic-level planning processes, as will be discussed in the next section (BC MAL 2006).

In summary, there have been a variety opportunities for public participation in $\mathrm{BC}$ forest management since the late 1970s. As outlined in Table 1, these opportunities (past and present) can be classified into three categories: operational, strategic and ad hoc.

Operational opportunities include those legislated under the Forest Act, the Code, and now FRPA. They are "site-specific," relate to relatively small tracts of land, and are typically confined to "review and comment" types of non-deliberative opportunities. Public participation at the strategic level can entail extensive consensus-based opportunities that includes not only multiple stakeholders, but the general public as well. Examples include those opportunities made available through the original CORE, LRMP, and SRMP processes. Finally, there have been various opportunities in the history of BC's public partipation that have been established for a short time and for a specific purpose. These ad hoc opportunities can involve a variety of types and levels of participation, examples of which include: Dunsmuir I and Dunsmuir II, the BC Round Table on the Environment and Economy, the Protected Areas Strategy, the Old Growth Strategy and other opportunities created through provincial Commissions.

\section{Complaints, the Future of strategic planning, and Discussion}

Although there have been various opportunities for public participation in BC since the late 1970s, the number of opportunities is clearly not all that matters. From the earlier discussion concerning deliberative democracy, recall that the ISS and White's "rules" attach great importance to the quality of public decision-making processes in the public sphere. This normative position supports inclusive public decisionmaking processes where participants are free from compulsion, and allows for all stated proposals to be brought into question. Arguments are defended with the public use of reason, a necessary condition for legitimacy. With these ideas in mind, this section is limited to examining public participation as legislated under FRPA and within land-use planning as currently administered by the ILMB. Recent public complaints and changes to strategic-level participatory opportunities are explored. As oppose to conducting a formal evaluation, however, the intention of this section is to critically 
examine public participation in $\mathrm{BC}$ forest management to inform the policy-level recommendations in the next section.

The main source of information concerning public complaints and public participation in $\mathrm{BC}$ forest management is the FPB. As mentioned in the previous section, the board was established when the Code came into effect in the mid-1990s. Since this time, a primary duty of this body has been to field complaints relating to forest management on public lands in general. Today, the FPB has a similar mandate under the FRPA legislation where the only opportunity for public participation is at the operational level-through reviewing and making comments on Forest Stewardship Plans (FSPs) (formerly Forest Development Plans).

It is estimated that approximately $25 \%$ to $33 \%$ of all public complaints received at the board relate to the inadequacy of opportunities to participate in FSPs. ${ }^{17}$ These complaints have focused on the inadequacy of time allowed for review and comment, insufficient public notification about plan development and the opportunity for review and comment, inadequacy of materials (plans, maps) for public review, the unavailability of technical information for public review, and the inadequacy of responses by licensees and the BC MoFR to public concerns about operational plans (FPB 2002). In reaction to these complaints, the board endeavoured to investigate and subsequently evaluate public participation under FRPA. In its conclusion, the report confirmed the validity of the public complaints, stating, "Overall, FRPA's requirements for public involvement in operational planning are minimal and do not or cannot meet or address many of the principles of effective public consultation... FRPA will not achieve effective consultation in most cases" (FPB 2004). The criteria employed by the board to evaluate "effective public involvement" include the following: early and meaningful, sufficient time, adequately resourced, inclusive, informative and accessible, responsive and genuine, verifiable and continuous.

Most recently, the board also officially commented on the first round of FSPs received by the province, and stated that they did not foster positive public perception "at all" (FPB 2006). Public participation at the operational level is currently "...unsuitable for public review and comment" (FPB 2006), and the FSPs are "...written in a complex legal language that makes them extremely difficult for the public to understand" (FPB 2006). The public complaints, and the evaluative work conducted by the board make clear that both the public and the official supervisory body for public forestry have serious concerns about the current opportunities for public participation at the operational level.

Interestingly, the public's response to public participation legislated under FRPA contrasts greatly with the general feedback concerning strategic-level public participation. In fact, the traditional consensus-based, multi-stakeholder LRMP process in particular has been praised by several sources for reducing conflict and establishing durable land-use plans through consensus-based public participation (Frame 2002, Frame et al. 2004). After assessing the LRMP process against their evaluative criteria, Frame et al. (2004) states, "Overall,

\footnotetext{
${ }^{17}$ In FPB (2002), it states "Nearly one-third of the Board's complaint investigations involved concerns about public review and comment on operational plans." FPB (Vol. 3) states, "About onequarter of the public complaints to the Board have to do with the opportunity for public review and comment..."
}

the experiment with the collaborative planning process in land-use planning in British Columbia was a remarkable success in promoting agreement among stakeholders who during the 1980s had become antagonistic and conflictive." Not surprisingly, another key outcome of the LRMP process is the sense of legitimacy experienced by participants. Following indepth interviews with participants of the LRMP process, Mascarenas and Scarce (2004) conclude, “...the legitimacy of the decision-making process is far more significant than the actual plan itself."

Although the early LRMP process was generally wellreceived, there have been some recent changes to strategiclevel participatory opportunities. Beginning in 2001, the LRMP process was streamlined and the decision was made to not initiate any more new LRMPs. ${ }^{18}$ Also around this time, according to some participants in the Sea-to-Sky LRMP, the process became government-led as opposed to stakeholderled, deadlines were enforced, and consensus, although sought, was no longer a requirement. ${ }^{19}$ Recently, the transformative trend of strategic-level planning was officially endorsed by the ILMB vis-à-vis its recommendation to conclude the LRMP process (BC MAL 2006). This decision stemmed mainly from the high financial cost involved with SLUP and the new direction of the "government's strategic values," which entails providing certainty to users of the landbase and ensuring that government retains its role as the final decision-maker. The report recommends that consensus-based strategic processes be officially replaced by a government-led decision-making process that is exclusive to key stakeholders. Moreover, these select stakeholders are to have an "advisory capacity" only. Such changes, if implemented, will result in a provincial landuse planning process that is remarkably different than the inclusive and decentralized process of the 1990s.

While the FPB has labelled public participation at the operational-level inadequate, it appears that the once-championed, strategic-level public participation intensive process will soon be replaced by a government-led operation with significantly diminished levels of inclusion. Arguably, this situation is particularly inapt considering the importance attached to public participation by the public, as highlighted by recent survey findings conducted by $\mathrm{BC}$ Stats and the BC MoFR. Apparently, public participation takes center stage when confronting distrust in provincial forest management. The surveys found that public trust levels declined between 2002 and 2004 (from 59\% to 52\%) ${ }^{20}$, and when citizens were asked how to increase the public's confidence in $\mathrm{BC}$ forest management, the number-one answer was to enhance transparency, public education and participation (BC Statistics 2005).

Given the status and foreseeable direction of public participation, likely problems could easily develop if the LRMP

\footnotetext{
${ }^{18}$ See MSRM (2001) concerning the LRMPs being streamlined. After a provincial election in 2001, "A decision was made not to initiate any new LRMPs." BC MAL (2006).

${ }^{19}$ In a letter dated December 20, 2004 entitled, Sea to Sky LRMP Update by Pat Harrison and Michael Feller, it states "Unlike previous LRMPs, the process was supposed to last for a year, was supposed to be government-led, rather than stakeholder-led, and it did not have to reach consensus among the stakeholders."

${ }^{20} \mathrm{An}$ independent T-test revealed a significant mean difference between 2002 and 2004 (BC Statistics 2005). The 59\% finding is accurate within $+/-3.6 \%, 19 / 20$ (Bredin 2003), while the $52 \%$ finding is accurate within $+/-3.3 \%, 19 / 20$ (BC Statistics 2005).
} 
process is transformed as described above and/or if the concerns raised by the FPB are not addressed. While the public complaints received by the FPB reflect a certain deficit in the quality of participatory opportunities, the charge of inadequacy by the FPB itself can be likened to operational-level public participation coming up far too short of meeting the ideals set out by the ISS. Similarly, at the strategic-level, although the LRMP process has received a favourable response in the past, it will be increasingly difficult for an exclusive, government-led decision-making process to meet the theoretical standards set out by White's "rules," or indeed, even the more practical evaluative criteria set out by Frame et al. (2004).

Though the ILMB has wisely sought a more efficient strategic-level planning process (to reduce the financial burden), without the inclusive representation of participants once endorsed by the LRMP process the legitimacy of planning could be in jeopardy. While efficiency and cost-cutting are important measures to take in some circumstances, the apparent trade-off between legitimacy and efficiency should not be underestimated. ${ }^{21}$ A cost-benefit analysis used to decide on the future direction of the LRMP process must not only consider the short-term financial commitments, but the "cost" of choosing a public decision-making process that diminishes the public use of reason, and thus, legitimacy in the eyes of the citizenry. The deterioration of legitimacy could easily disrupt the public acceptability and stability of forest management and land-use plans. The consequence could eventually result in a sharpened struggle over resources where processes become considerably more time-consuming and costly (McGuire and Sanyal 2006). Indeed, one need only look back to the scenes of Clayoquot Sound in the early 1990 s to recognize the potential damage and would-be consequences of neglecting legitimacy in forest management.

\section{Policy Recommendations for Public Participation}

With an understanding of public participation deriving from deliberative democratic theory, its history in BC forestry, and through an examination of public complaints and the current direction of strategic level planning, several practical steps can be taken to improve it at the policy level. Most pressing perhaps is the development of a comprehensive ministerial public participation policy that outlines the categories and opportunities for different forms of public participation in BC forest management. Not since the early 1980s has there been such a policy at the BC MoFR. The latest Ministerial Policy Manual has reserved a space for a Public Involvement Policy, but, as previously mentioned, it has been in progress since $1993 .^{22}$ Effective opportunities for public participation are central to the contemporary management of public forests and a comprehensive ministerial policy should finally be devised to reflect this.

Public participation in BC forest management would benefit from a transparent mechanism clearly explaining (1) how

\footnotetext{
${ }^{21}$ The reality of this trade-off is underscored by deLeon (1995) where he argues that contemporary policy is too concerned with efficiency and not enough with democratic legitimacy.

${ }^{22}$ Similarly, "Public Involvement" is Indicator 20 in the first State of British Columbia's Forests Report (released March 10, 1995), but it, too, is a work in progress. See http://www.for.gov.bc.ca/hfp/ sof/sof.htm
}

the public interest is determined and (2) how it is sanctioned through governmental decisions and actions relating to forest management. Because the work of managers is largely guided by the public interest, such an arrangement would better enable effective participatory opportunities — ones that align with the public's preference. Heeding the recommendations of the FPB and striving to meet their evaluative criteria would also be an effective step towards strengthening participatory opportunities at the operational level.

Disseminating information to the public about opportunities for public participation in forest management would also help to improve it. While the public is responsible to seek information about opportunities to participate, the effective manager would do well to make that information easily accessible. Much like citizens generally know how MLAs are elected, the public would benefit from knowing exactly how they can participate in forest management and where they can get such information. Currently, it can be a struggle for citizens looking for information about opportunities to participate. Although there is a helpful ILMB Web site that provides ample information about public participation in SLUP, someone seeking information about all opportunities for participation specific to provincial forest management will be disappointed. A centralized one-stop "portal" that is specific to public participation in forest management would greatly enhance the flow of information while informing the public of opportunities.

The BC MoFR, like many other government agencies today, is administered vis-à-vis a performance-based management system and, thus, incorporating effective public participation as an objective in the ministerial results-based framework would not be a difficult task. By establishing official criteria for effectiveness and making it a part of the dayto-day discourse, it would improve the likelihood of enhancing the quality of participatory opportunities. The United States Environmental Protection Agency recently evolved to a similar position when it adopted a public participation evaluation project created by its staff (Charnley and Engelbert 2005). By incorporating effective public participation as a stated goal of the BC MoFR, there would be much to gain with little cost incurred.

Finally, if the LRMP process is going to be concluded (this decision appears to lie outside of the BC MoFR), it will be important to recognize how these changes will impact legitimacy in forest management specifically. Is it possible for the province-wide SLUP to be replaced by another inclusive, legitimating process that is specific to forest management? Perhaps the recent BC Citizens' Assembly on Electoral Reform could provide some useful insight in this regard. ${ }^{23}$

\section{Conclusion}

Public participation is a complex, ever-evolving phenomenon that can take on a variety of forms, degrees, and types. Although the non-existence of objective criteria makes measuring the effectiveness of participatory opportunities difficult, an abundance of theoretical and empirical literature provides ample information to direct its improvement. In the framework of deliberative democratic theory, legitimacy derives from the public use of reason between free and equal participants. Central to the desire for public participation in

\footnotetext{
${ }^{23}$ See www.citizensassembly.bc.ca
} 
a society moving towards a more participatory form of democracy is the need for legitimacy vis-à-vis the public use of reason in collective decision-making.

A history of public participation in BC forest management demonstrated that participatory opportunities have existed at three main levels of decision-making (the operational, strategic, and ad hoc). Although there has been a legislative requirement for public participation in forest management since the late 1970s, its current impact is minimal and it is not supported by a corresponding policy. A main objective of this paper was to acknowledge the recent public complaints about public participation in light of the opportunities available. According to the evaluations conducted by the FPB, public participation under FRPA is inadequate. Moreover, at the strategic-level of planning, if the recommendations for concluding SLUP are carried out, the opportunities to participate will be reduced considerably. With a significant cutback in participatory opportunities for the general public at one level of planning, and avowed inadequacies on another, a dwindling of the "public use of reason" and an ensuing impact on the public's sense of legitimacy is looming. Nevertheless, there are practical steps that can be taken to improve the state of public participation in BC forestry, including formulating a ministerial policy and adopting "effective public participation" as a results-based objective.

\section{Acknowledgements}

I am indebted to Bill Wagner, Sen Wang, Brian Peter, Bill Wilson, Brad Stennes, Al Niezen, Kelvin Eisses, Bruce Fraser, Carl Withler and two anonymous reviewers for valuable discussions and helpful comments on earlier versions of this paper. Any errors are the responsibility of the author-all of the usual disclaimers apply.

\section{References}

Abelson, J., P-G. Forest, J. Eyles, P. Smith, E. Martin and F-P. Gauvin. 2003. Deliberations about deliberative methods: issues in the design and evaluation of public participation processes. Soc. Sci. and Med. 57: 239-251.

Association of British Columbia Professional Foresters. 2002. Interpreting the Publics' Interests. [online]. Available from: http:// www.opfa.ca/pdfs/BCPublicInterestDiscussionPaper.pdf [Accessed 15 June 2007].

Beckley, T.M., J.R. Parkins and S.R.J. Sheppard. 2006. Public participation in sustainable forest management: a reference guide. Sustainable Forest Management Network. Canada. Available at: http://nofc.cfs.nrcan.gc.ca/bookstore_pdfs/26206.pdf [Accessed 15 June 2007].

Bohman, J. 2000. Public deliberation: pluralism, complexity and democracy. MIT Press, Cambridge, MA. 303 p.

Bredin, J. 2003. A benchmark of public trust in the British Columbia Forest Service. A management report submitted in partial fulfillment of the requirements for the Degree of Master of Public Administration, University of Victoria, Victoria, BC. 91 p.

Brenneis, K. 1990. An evaluation of public participation in the British Columbia Ministry of Forests. Forest Resources Commission, Background papers, Vol. 1. Victoria, BC.

British Columbia. 1993. Land and Resource Management Planning Public Participation Guidelines. Victoria. Available at: http://ilmbwww.gov.bc.ca/lup/policies_guides/lrmp_policy/guidelns.htm [Accessed 15 June 2007].

British Columbia Ministry of Agriculture and Lands (BC MAL). 2006. A New Direction for Strategic Land Use Planning in BC. Integrated Land Management Bureau, Victoria. Available at: http://ilmbwww.gov.bc.ca/lup/policies_guides/new_direction/new \%20direction\%20synopsis.pdf [Accessed 12 March 2007].

British Columbia Ministry of Forests (BC MoF). 1981. Public involvement handbook. Queen's Printer Publications, Victoria, BC. British Columbia Ministry of Forests (BC MoF). 1984. Resource planning manual. British Columbia Ministry of Forests, Victoria, BC. BC Statistics. 2005. An Evaluation of public trust in the British Columbia Forest Service. Service BC, Ministry of Management Services, Victoria, BC.

Canadian Council of Forest Ministers (CCFM). 1992. Sustainable forests: a Canadian commitment. National forest strategy. Canadian Council of Forest Ministers. Hull, QC. 51 p.

Canadian Institute of Forestry (CIF). 1998. Public participation in decision-making about forests. Canadian Institute of Forestry position paper. Canadian Institute of Forestry, Ottawa.. Available at http://www.cif-ifc.org/pdfs/policypos/E-Pos-6-Public_ Participation.pdf [Accessed 9 January 2007].

Chambers, S. 1996. Reasonable democracy: Jürgen Habermas and the politics of discourse. Cornell University Press, Ithaca, NY. 250 p. Charnley, S. and B. Engelbert. 2005. Evaluating public participation in environmental decision-making: EPA's superfund community involvement program. J. Environ. Manage. 77: 165-182.

Cohen, J. 1997. Deliberation and democratic legitimacy. In J. Bohman and W. Rehg (eds.). Deliberative democracy: essays on reason and politics. pp. 67-91. MIT Press, Cambridge, MA. 480 p.

Commission on Resources and Environment (CORE). 1993. Commissioner on Resources and Environment Act, Chapter 34. pp. 1-5 (Appendix 1), CORE 1995b. British Columbia's Strategy for Sustainability: Report to the Legislative Assembly, 1994-95. Commission on Resources and Environment. Victoria.

Commission on Resources and Environment (CORE). 1995a. The provincial land use strategy, Vol.3, Public participation. Commission on Resources and Environment, Victoria, BC.

Commission on Resources and Environment (CORE). 1995b. British Columbia's Strategy for Sustainability: Report to the Legislative Assembly, 1994-95. Commission on Resources and Environment, Victoria, BC.

Conley, A. and M.A. Moote. 2003. Evaluating Collaborative Natural Resource Management. Soc. \& Nat. Res.16: 371-386.

Cronin, C. 1993. Translator's Introduction. In J. Habermas. Justification and Application: Remarks on Discourse Ethics. pp. xixxxi. MIT Press, Cambridge, MA. 229 p.

deLeon, P. 1995. Democratic values and the policy science. Ame. J. Pol. Sci. 39: 886-905.

Doliner, L.H. 1982. Summary of responses to Ministry of Forests public involvement policy and practice. Victoria, BC.

Duinker, P.N. 1998. Public Participation's promising progress: advances in forest decision-making in Canada. Com. For. Rev. 77: $107-112$.

FAO. 2004. Public participation in forestry in Europe and North America. Joint FAO/ECE/ILO Committee on Forest Technology, Management and Training. Geneva. International Labour Office [online]. Available at: http://www.unece.org/trade/timber/jointcommittee/participation/report.pdf [Accessed 28 March 2007].

Forest Land Use Liaison Committee. 1978. Forest land use liaison committee consensus statement on public involvement. Victoria.

Forest Practices Board (FPB). Undated. Board Bulletin, Volume 3 Opportunity for Public Consultation under the Forest and Range Practices Act [online]. Available at http://www.fpb.gov.bc.ca/bulletins/Opportunity.pdf [Accessed 28 March 2007].

Forest Practices Board (FPB). 2002. Public complaints about Forest Planning and Practice: 1995-2001 [online]. Available at www.fpb. gov.bc.ca/special/reports/Roll_ups/complaints.htm [Accessed 28 March 2007].

Forest Practices Board (FPB). 2006. A review of the early forest stewardship plans under FRPA: A special report [online]. Available at: http://www.fpb.gov.bc.ca/special/reports/SR28/SR28.pdf [Accessed 28 March 2007]. 
Forest Resources Commission (FRC). 1991. The future of our forests. Forest Resources Commission, Victoria, BC.

Frame, T.M. 2002. Shared Decision Making and Sustainability: An Evaluation of Land and Resource Management Planning in British Columbia. Master of Resource Management Research Project. 87 p. Available at http://www.rem.sfu.ca/sustainableplanning/NewFiles/ Tanis\%20Frame\%20Masters\%20Thesis.pdf [Accessed 14 June 2007]. Frame, T.M., T. Gunton and J.C. Day. 2004. The Role of Collaboration in Environmental Management: An Evaluation of Land and Resource Planning in British Columbia. J. Environ. Plann. Manag. 47(1): 59-82.

Grzybowski and Associates. 2001. Regional environmental effects assessment and strategic land use planning in British Columbia.

Gunton, T.I. and J.C. Day. 2003. The theory and practice of collaborative planning in resource and environmental management. Env. 31: 5-21.

Gutmann, A. and D. Thompson. 2004. Why deliberative democracy? Princeton University Press. Princeton, NJ. 256 p.

Habermas, J. 1993. Justification and application: remarks on discourse ethics. Translated by C.P. Cronin. MIT Press, Cambridge, MA. 229 p.

Mascarenas, M. and R. Scarce. 2004. The intention was good: legitimacy, consensus-based decision making, and the case of forest planning in British Columbia, Canada. Soc. \& Nat. Res. 17: 17-38.

McGuire, K. and N. Sanyal. 2006. A human dimensions inquiry in watershed analysis: listening to constituents' views of contested legitimacy on the natural forest. Soc. \& Nat. Res. 19: 889-904.

Ministry of Sustainable Resource Management (MSRM). 2001. Review leads to streamlined land-use planning. British Columbia news release. Available at http://ilmbwww.gov.bc.ca/lup/lrmp/ coast/cencoast/news/nr111501.htm [Accessed 4 June 2007].
Montpetit, É. 2003. Public consultations in policy network environments: the case of assisted reproductive technology policy in Canada. Can. Pub. Pol. 29(1): 95-110.

Niezen, A. 1987. The efficiency and effectiveness of public involvement in multiple use issues in BC: a professional report to the association of BC professional foresters. Victoria, BC.

Parkins, J.R. 2002. Forest management and advisory groups in Alberta: an empirical critique of an emergent public sphere. Can. J. of Soc. 27(2): 163-184.

Posner, R.A.. 2003. Law, Pragmatism and Democracy. Harvard University Press, Cambridge, MA. 398 p.

Rowe, G. and L.J. Frewer. 2004. Evaluating public participation Exercises: a research agenda. Sci. Tech. \& Hum. Val. 29(4): 512-556. Sheppard, S.R.J and C.M. Achiam. 2004. Public participation in forest decision making. In Encyclopedia of Forest Sciences, Vol. 3. pp. 1173-1182. Academic Press, London.

Stedman, R.C. and J.R. Parkins. 2004. Public involvement in forest management: toward a research program in Alberta. In B.A. Shindler, T.M. Beckley and M.C. Finley (eds.). Two paths toward sustainable forests: public values in Canada and the United States. pp. 131-148. Oregon State University Press, Corvallis, OR. 359 p.

Webler, T. 1995. "Right" discourse in citizen participation: an evaluative yardstick. In O.T. Renn, T. Webler and P. Wiedemann (eds.). Fairness and competence in citizen participation. pp.35-86. Kluwer Academic Publishers, Boston, MA. 408 p.

Wilson, J. 1998. Talk and log: wilderness politics in British Columbia. UBC Press, Vancouver, BC. 452 p.

White, S.K. 1988. The recent work of Jürgen Habermas: Reason, justice and modernity. Cambridge University Press, Cambridge, UK. 190 p. World Commission on Environment and Development. 1987. Our Common Future. United Nations, New York. 400 p. 